\title{
RESPON UMKM KECAMATAN AMPENAN KOTA MATARAM ATAS DIBERLAKUKANNYA PERATURAN PEMERINTAH NOMOR 46 TAHUN 2013 MENGENAI PENGENAAN TARIF PAJAK 1\%
}

\author{
Siti Fatimah \\ Fakultas Ekonomi dan Bisnis Universitas Mataram \\ SitiFatimah@unram.ac.id \\ Muhammad Alwi \\ Fakultas Ekonomi dan Bisnis Universitas Mataram \\ Muhnurrahmah303@gmail.com \\ I Dewa Ketut Yudha S. \\ Fakultas Ekonomi dan Bisnis Universitas Mataram \\ dewayudha1229@gmail.com
}

\begin{abstract}
ABSTRAK
Penelitian ini bertujuan untuk menganalisis tingkat pemahaman dari Wajib Pajak UMKM tehadap pemberlakuan peraturan pemerintah no 46 tahun 2013 mengenai tarif pajak $1 \%$ dari peredaran bruto, dan menganalisis respon UMKM terhadap Peraturan pemerintah tahun 2013 dengan menggunakan data kuantitatif dan kualitatif . Data diperoleh dari wancara langsung dengan mengisi kuiseuner oleh 25 responden pengusahaUMKM di Kecamatan Ampenan, selain itu juga diporeleh data kualitatif berupa informasi melalui Fokus Group Diccussion (FGD) . Metode yang digunakan dalam pemilihan responden adalah menggunakan metode purpose sampling yang dipadukan dengan dengan Snowball sampling yang disesuaikan kebutuhan dengan alasan mempunyai kharateristik yang sama diantarnya dalam hal peredaran bruto lebih kecil atau sama dengan Rp 4,8 Milyar. Di samping itu juga diperoleh dalam informasi pada Fokus Group discustion (FGD) pada waktu melakukan kegiatan pengabdian pada masyarakat sebanyak 21 peserta dari WP UMKM . Hasil penelitian menunjukan bahwa ; 1. Pada umumnya WP UMKM di Kecamatan Ampenan memahami peraturan pemerintah No 46 tahun 2013. 2. Respon Wajib pajakak UMKM terhada PP no 46 tahun 2013, ada positif dan ada yang negatif. Respon positif adalah terpenuhi asas kemudahan menghitung pajak dan respon negative adalah asas keadilan tidak terpenuhi karena WP UMKM merasa berat dalam penuhan kewajiban perpajakannya setiap bulan sehingga WP menjadi tidak patuh. Disarankan kepada Dirjen Pajak agar merevisi PP 46 tahun 2013 tentang tarif $1 \%$ terhadap omset penjualan perbulan dengan cara menurukan tarif.
\end{abstract}

Kata Kunci: PP 46 tahun 2013, PPh UMKM 


\section{ABSTRAC}

Micro, Small and Medium Enterprises (UMKM) towards the enactment of government regulation No. 46 of 2013 concerning the tax rate of $1 \%$ of gross circulation, and analyzing the response of MSMEs to this study aimed at analyzing the level of understanding of micro business taxpayers in 2013 using quantitative data and qualitative. Data were obtained from direct interviews by filling out questionnaires by 25 UMKM entrepreneurs in Ampenan Subdistrict, besides that, qualitative data were also obtained in the form of information through Focus Group Diccussion (FGD). The method used in the selection of respondents is to use a purpose sampling method combined with snowball sampling that is tailored to the needs for the reason that they have the same characteristics including in terms of gross circulation smaller or equal to Rp. 4.8 billion. In addition, information was also obtained from the Focus Group Discustion (FGD) on 21 community members from the UMKM WP. The results of the study show that; 1. In general, UMKM WPS in Ampenan sub-district understand government regulation No. 46 of 2013. 2. The UMKM taxpayer's response to PP No. 46 of 2013 is positive and there are negative ones. Positive response is fulfilled the principle of easy tax calculation and negative response is the principle of justice is not fulfilled because the UMKM WP feels heavy in fulfilling its tax obligations every month so that the WP becomes disobedient. It is recommended to the Directorate General of Taxes to revise PP 46 of 2013 concerning a 1\% tariff on monthly sales turnover by reducing tariffs.

\section{Keywords: Response of UMKM PP. No. 462013}

\section{Latar Belakang}

\section{PENDAHULUAN}

Pemerintah di tahun 2013 mengeluarkan peraturan baru yaitu Peraturan Pemerintah Nomor 46. Peraturan ini mulai aktif diberlakukan mulai 1 Juli 2013 dan mengatur perlakuan khusus tentang pengenaan Pajak Penghasilan (PPh) atas usaha dengan omzet tertentu, atau dikenal juga dengan istilah PPh untuk usaha mikro, kecil dan menengah (UMKM). Pemberlakuan peraturan pemerintah ini menuai pro dan kontra di tengah masyarakat terutama UMKM sendiri dengan berbagai pihak.

Wajib Pajak yang dikenai dalam Pajak Penghasilan sesuai PP 46 Tahun 2013 adalah orang pribadi maupun badan, tidak termasuk BUT (Bentuk Usaha Tetap), namun terdapat pengecualian yaitu orang pribadi yang melakukan kegiatan usaha perdagangan dan atau jasa yang menggunakan sarana yang dapat dibongkar pasang dan menggunakan sebagian atau seluruh tempat usaha untuk kepentingan umum, misalnya pedagang keliling, pedagang asongan, warung tenda di area kaki lima, dan sejenisnya. Untuk Wajib Pajak Badan, apabila belum beroperasi secara komersial atau yang dalam jangka waktu 1 (satu) tahun setelah beroperasi komersial memperoleh peredaran bruto (omzet) Rp 4,8 miliar. Dengan demikian orang pribadi atau badan tersebut wajib melaksanakan ketentuan perpajakan sesuai dengan UU KUP maupun UU PPh secara umum. Pengenaan pajak ini memang sedikit menyulitkan para pelaku 
usaha karena industri ini cenderung berhati-hati dalam pengeluaran biaya karena banyak hal yang harus diperhitungkan mulai dari proses produksi sampai penjualan. Namun Wakil Ketua Umum Kadin UMKM Erwin Aksa mengatakan pemberlakuan tarif pajak 1 persen jangan dijadikan beban namun menjadi daya ungkit agar pelaku UMKM utamanya pengusaha kecil bisa naik kelas atau scaling up bisnis para UMKM. Menurutnya, pihak perbankan tidak berani memberikan kredit pengembangan usaha bagi usaha yang belum bankable, memiliki laporan keuangan, tata kelola yang bagus serta membayar pajak (Aksa, 2013).

Hal ini bertentangan dengan yang diungkapkan oleh Aziz Bachtiar selaku Sekretaris Jenderal (Sekjen) Asosiasi Eksportir dan Produsen Handycraft Indonesia (Asephi) Badan Pengurus Cabang Surakarta, sebenarnya kebijakan tersebut bisa berdampak buruk bagi UMKM karena mayoritas anggotanya bergerak dalam usaha mikro kecil dan menengah (UMKM) laba yang masih sangat minim (Bachtiar, 2013).

Kecamatan Ampenan adalah salah satu kecamatan yang ada di wlayah kota Mataram yang banyak berkembang UMKM. Berbagai jenis usaha yang dilakukan oleh UMKM sepeti usaha perdagangan, industry dan jasa-jasa. UMKM Kecamatan Ampenan sebagai salah satu pusat perdagangaan sejak jaman Belanda sampai sekarang tentu banyak sekali UMKM karena sepanjang jalan penuh pertokoan dengan berbagai macam bidang usaha, disamping itu banyak usaha usaha kecil ada didalam perkampungan penduduk di Kecamatan Ampenan seperti usaha uasah keripik, roti dan lainnya. Adapun jumlah penduduk Kecamatan Ampenan menurut jenis pekerjaan Nampak pada tabel berikut ini;

Tabel 1. Penduduk Kecamatan Ampenan Menurut Jenis Pekerjaan PENDUDUK KECAMATAN AMPENAN MENURUT JENIS PEKERIAAN

\begin{tabular}{|clcccccccc|}
\hline No & KELURAHAN & Peg. N & Peg .S & DOKTER & W. USAHA & TNI/POLRI & NELAYAN & BURUH & LAINNYA \\
\hline 1 & Taman Sari & 884 & 1,720 & 15 & 635 & 396 & 2 & 160 & 1,180 \\
\hline 2 & Ampenan Selatan & 384 & 1,252 & 8 & 999 & 339 & 172 & 510 & 1,493 \\
\hline 3 & Banjar & 283 & 1,041 & 6 & 1,035 & 29 & 81 & 430 & 1,192 \\
\hline 4 & Ampenan Tengah & 425 & 1,574 & 7 & 1,605 & 45 & 50 & 337 & 2,075 \\
\hline 5 & Bintaro & 117 & 971 & 5 & 1,001 & 19 & 848 & 497 & 2,084 \\
\hline 6 & Dayan Peken & 274 & 1,339 & 9 & 1,254 & 30 & 9 & 551 & 1,774 \\
\hline 7 & Ampenan Utara & 242 & 862 & 3 & 1,102 & 21 & 4 & 445 & 1,291 \\
\hline 8 & Pejeruk & 588 & 1,371 & 10 & 1,474 & 43 & 0 & 431 & 1,711 \\
\hline 9 & Kebon Sari & 778 & 999 & 3 & 639 & 36 & 0 & 367 & 1,237 \\
\hline 10 & Pejarakan Karya & 397 & 818 & 3 & 624 & 31 & 0 & 453 & 1,056 \\
\hline & & 4,372 & 11,947 & 69 & 10,368 & 989 & 1,166 & 4,181 & 15,093 \\
\hline
\end{tabular}

Sumber: Profil Kecamatan Ampenan

Berdasarkan pada tabel di atas terlihat jumlah penduduk Ampenan menurut jenis pekerjaannya yang terbanyak adalah bekerja sebagai wira Usaha yang didalamnya termasuk Usaha Mikro Kecil dan Menengah (UMKM). Dimana tidak semua wira usaha 
dan UMKM dikenakan tarif $1 \%$ dari jumlah peredaran Bruto dan bersifat final seperti sepenghasilan jasa dari pekerjaan bebas, Wajib Pajak orang Pribadi yang melakukan perdagangan barang dalam usahanya dengan menggunakan sarana dan prasarana yang dapat dibongkar pasang, begitu pula wajib pajak badan yang beroperasi secara komersial dan memperoleh peredaran Bruto melebihi 4,8 milyar.

\section{Perumusan Masalah}

Bagaimana respon atau tanggapan UMKM yang terdapat di Kecamatan Ampenan tersebut terhadap Peraturan Pemerintah No 46 Tahun 2013?

\section{Tujuan Penelitian}

Tujuan dari penelitian ini adalah sebagai berikut :

1. Menganalisis tingkat pemahaman UMKM terhadap pemberlakuan Peraturan Pemerintah Nomor 46 Tahun 2013 mengenai pajak 1\% UMKM

2. Menganalisis respon UMKM terhadap pemberlakuan Peraturan Pemerintah Nomor 46 Tahun 2013 mengenai pajak 1\% UMKM.

\section{TELAAH LITERATUR DAN PENGEMBANGAN HIPOTESIS}

\section{Pengertian UMKM}

Menurut Undang-Undang No. 20 Tahun 2008, usaha mikro adalah usaha produktif milik orang perorangan dan atau badan usaha perorangan yang memenuhi kriteria. Usaha Mikro sebagaimana diatur dalam Undang-Undang. Padahal sebenarnya UMKM sangat berperan dalam mengurangi tingkat pengangguran yang ada di Indonesia. UMKM dapat menyerap banyak tenaga kerja Indonesia yang masih mengganggur. Selain itu UMKM telah berkontribusi besar pada pendapatan daerah maupun pendapatan negara Indonesia.

UMKM juga memanfaatkan berbagai sumber daya alam yang berpotensial di suatu daerah yang belum diolah secara komersial. UMKM dapat membantu mengolah sumber daya alam yang ada di setiap daerah. Hal ini berkontribusi besar terhadap pendapatan daerah maupun pendapatan negara Indonesia.

Usaha Kecil, yang merupakan bagian integral dunia usaha nasional mempunyai kedudukan, potensi dan peranan yang sangat penting dan strategis dalam mewujudkan tujuan Pembangunan Nasional pada umumnya dan tujuan pembangunan ekonomi pada khususnya. usaha kecil merupakan kegiatan usaha yang mampu memperluas lapangan kerja dan memberikan pelayanan ekonomi yang luas pada masyarakat dapat berperan dalam proses pemerataan dan meningkatkan pendapatan masyarakat, serta mendorong pertumbuhan ekonomi dan berperan dalam mewujudkan stabilitas nasional pada umumnya dan stabilitas pada khususnya.

Usaha Kecil adalah kegiatan ekonomi rakyat yang berskala kecil dan memenuhi kriteria kekayaan bersih atau hasil penjualan tahunan. Kekayaan bersih adalah nilai jual kekayaan usaha (asset) dikurangi kewajibannya. Sedangkan yang dimaksud dengan 
hasil penjualan tahunan adalah hasil penjualan bersih (netto) yang berasal dari penjualan barang dan jasa dari usahanya dalam satu tahun buku.

\section{Kriteria Usaha Kecil Menengah (Sobarudin, 2013):}

a. Memiliki kekayaan bersih paling banyak Rp.200.000.000 (dua ratus juta rupiah), tidak termasuk tanah dan bangunan tempat usaha atau

b. Memiliki hasil penjualan tahunan paling banyak Rp. 1.000.000.000 (satu milyar rupiah);

c. Milik Warga Negara Indonesia;

d. Berdiri sendiri, bukan merupakan anak perusahaan atau cabang perusahaan yang dimiliki, dikuasai, atau berafiliasi baik langsung maupun tidak langsung dengan Usaha Menengah atau Usaha Besar;

e. Berbentuk usaha orang perseorangan, badan usaha yang tidak berbadan hukum, atau badan usaha yang berbadan hukum, termasuk koperasi.

\section{Kriteria Wajib Pajak yang memenuhi syrat ketentuan PP 46 tahun 2013}

Dengan berlakunya Peraturan Pemerintah Nomor 46 Tahun 2013 tentang pengenaan PPh dari usaha yang diterima atau diperoleh Wajib Pajak yang memiliki peredaran bruto tertentu sejak 1 Juli 2013, maka seluruh Wajib Pajak Badan dan Orang Pribadi yang memenuhi ketentuan dalam peraturan ini sudah harus mengubah penghitungan, penyetoran dan pelaporan PPh atas penghasilan yang diterimanya. Apabila selama ini, penghasilan yang diterimanya adalah merupakan penghasilan yang harus dihitung dalam SPT Tahunan PPh dan dikenakan PPh tarif Pasal 17 UU PPh, maka sejak 1 Juli 2013, Wajib Pajak Orang Pribadi dan Badan yang memenuhi ketentuan PP Nomor 46 Tahun 2013 harus mengubah penghitungan PPh atas penghasilannya menjadi dikenakan PPh yang bersifat final sebesar $1 \%$ dari peredaran usaha bruto setiap bulannya.

Walaupun PP Nomor 46 Tahun 2013 telah berlaku 5 tahun, namun prakteknya di lapangan masih banyak menimbulkan pertanyaan dari para Wajib Pajak. Beberapa pertanyaan yang timbul seperti: apakah saya termasuk sebagai Wajib Pajak yang memiliki peredaran bruto tertentu, sebagaimana yang diatur di PP Nomor 46 Tahun 2013 ini? Siapa sajakah Wajib Pajak yang berhak untuk menerapkan pengenaan PPh yang bersifat final sebesar $1 \%$ ini? Jika kita simak ketentuan yang tercantum dalam Pasal 2 Peraturan Pemerintah Nomor 46 Tahun 2013 dan Pasal 2 Peraturan Menteri Keuangan Nomor 107/PMK.011/2013, maka dapat kita simpulkan bahwa Wajib Pajak yang harus menerapkan PP Nomor 46 Tahun 2013 ini adalah Wajib Pajak yang memiliki peredaran bruto tertentu.

Lebih lanjut ditegaskan bahwa Wajib Pajak yang memiliki peredaran bruto tertentu ini kriterianya adalah (Pasal 2 ayat (2) PP Nomor 46 Tahun 2013 dan Pasal 2 ayat (2) Peraturan Menteri Keuangan Nomor 107/PMK.011/2013): 
1. Wajib Pajak Orang Pribadi atau Wajib Pajak Badan (tidak termasuk Bentuk Usaha Tetap); dan

2. menerima penghasilan dari usaha, tidak termasuk penghasilan dari jasa sehubungan dengan pekerjaan bebas, dengan peredaran bruto tidak melebihi Rp4.800.000.000 (empat miliar delapan ratus juta rupiah) dalam 1 (satu) Tahun Pajak.

Jika menyimak aturan Pasal 2 ayat (2) pada kedua aturan ini, maka dapat kita lihat bahwa kedua persyaratan/kriteria tersebut harus terpenuhi seluruhnya dan bersifat kumulatif (karena dihubungkan dengan kata penghubung "dan").

\section{METODE PENELITIAN}

Jenis penelitian yang digunakan adalah penelitian deskriptif, yaitu suatu metode dalam meneliti status kelompok manusia, suatu objek, suatu kondisi, suatu system pemikiran ataupun suatu peristiwa pada masa sekarang guna membuat diskripsi, gambaran atau lukisan secara sistimatis, factual dan akurat mengenai fakta-fakta serta hubungan antara yang diselidiki, dianalisis kemudian disimpulkan. (Nazir, 1999: 63).

Lokasi penelitian dilakukan di Kecamatan Ampenan Kota Mataram , Alasan pemilihan lokasi ini karena UMKM di Kecamatan Ampenan merupakan kota yang tertua dan kota pelabuhan tentu banyak tumbuh UMKM

Populasi dalam penelitian ini adalah UMKM di Kecamatan Ampenan Kota Mataram. Sampel dalam penelitian ini sebanyak 25 UMKM di Kecamatan Ampenan yang diambil secara Porposive sampling dipadukan dengan Snowball sampling sesuai kebutuhan dengan alasan mempunyai kharateristik yang sama dalam hal peredaran bruto lebih kecil atau sama dengan Rp 4,8 Milyar. Di samping itu juga diperoleh dalam Fokus Group Discussion untuk data kualitatif pada waktu melaksanakan kegiatan pengabdian pada masyarakat sebanyak 21 pengusaha UMKM yang ada di kecamatan yaitu jenis sampel yang telah disesuaikan dengan kriteria sampel.

Jenis data yang digunakan dalam penelitian ini adalah data kuantitatif dan kualitatif dari sampel UMKM berupa tingkat pemahaman UMKM terhadap pemberlakuan Peraturan Pemerintah Nomor 46 Tahun 2013 mengenai pajak 1\% UMKM, dan respon UMKM terhadap pemberlakuan Peraturan Pemerintah Nomor 46 Tahun 2013.

Penelitian ini menggunakan dua jenis sumber data yaitu:

a. Data primer

Yaitu data yang diperoleh secara langsung dari responden pada lokasi penelitian. Data primer diperoleh dengan memberikan kuesioner kepada responden untuk diisi sesuai pertanyaan dalam kuesioner.

b. Data sekunder

Yaitu data yang diperoleh melalui studi pustaka, dengan mempelajari berbagai tulisan melalui buku, jurnal, untuk mendukung penelitian ini.

Pengumpulan data dalam penelitian ini dilakukan dengan cara memberikan kuisioner terhadap responden. Teknik pengumpulan data dengan mengajukan pertanyaan 
terlebih dahulu melalui daftar pertanyaan setiap responden UMKM untuk memperoleh data yang dibutuhkan sehingga penelitian dapat lebih terstruktur. Selain itu juga digunakan teknik pengumpulan data lewat Diskusi terpusat (Focus Group Discussion), yaitu upaya menemukan makna sebuah isu oleh sekelompok orang lewat diskusi untuk menghindari diri pemaknaan yang salah oleh seorang peneliti. Misalnya, Untuk menghindari pemaknaan secara subjektif oleh seorang peneliti, maka dibentuk kelompok diskusi terdiri atas beberapa orang peneliti dan 23 orang penguaha UMKM. Melalui Focus Group Discussion (FGD) diharapkan akan diperoleh hasil pemaknaan yang lebih objektif.

Metode analisis data adalah metode kuantitatif dengan menggunakan Tabulasi Silang (Cross Tab) sedangkan data kualitatif diperoleh dalam Focus Group Discussion (FGD)

\section{HASIL DAN PEMBAHASAN}

\section{Tingkat Pemahaman Pengusaha UMKM Terhadap Pemberlakuan PP No 46 Tahun 2013}

Umumnya pengusaha UMKM di Kecamatan Ampenan sudah memahami isi PP no 46 tahun 2013 tentang tarif $1 \%$ dari jumlah peredaran bruto perbulan dan bersifat final serta wajib pajak Orang Pribadi dan Wajib Pajak Badan yang dikeculikan dari PP No 46 tahun 2013. Penerapan peraturan perpajakan ini dapat dilakukan apabila WP UMKM memeliki peredaran Bruto kurang dari $\mathrm{Rp} 4,8$ milyar satu tahun sebelumnya. Berdasarkan data dari 25 responden pengusaha UMKM di Kecamatan Ampenan diktahui bahwa sebanyak 21 (84\%) pengusaha UMKM sudah memahami ketentuan peraturan ini. Tingginya tingkat pemahaman pengusaha UMKM di kecamatan Ampenan karena pemerintah dalam hal ini aparat pajak telah giat mengadakan sosialisasi secara langsung maupun tidak langsung. Berdasarkan data dari 25 responden pengusaha UMKM sebanyak 19 responden (76\%) mengetahui PP No 46 tahun 2013 melalui media resmi seperti TV, radio dan Koran, sedang secara langsung, dimana aparat pajak melakukan penyebaran informasi dengan cara mengadakan penyuluhan dan responden yang pernah dikuti sebanyak 20 responden $(80 \%)$ responden dari 25 responden. Sedangkan informasi yang diperoleh dalam kegiatan Focos Group Discussion (FGD) diperoleh informasi dari Pengusaha UMKM bahwa pada umumnya sudah memahami PP No 46 tahun 2013 dengan tariff 1\% dari jumlah peredaran bruto sebulan dan bersifat final dengan syarat jumlah peredaran bruto setahun sebelumnya kurang dari Rp 4,8 milyar.

\section{Respon Pengusaha UMKM Terhadap PP no 46 tahun 2013 dengan Tarif 1\%} Respon atau persepsi wajib pajak UMKM (Usaha Mikro Kecil dan Menengah) terhadap PP No. 46 tahun 2013 tentu akan menimbulkan berbagai tanggapan . Penerapan peraturan baru tersebut menimbulkan respon dari berbagai pihak, terutama dilihat dari 
pemenuhan asas kemudahan dan keadilan. Persepsi dari wajib pajak perlu diketahui karena memiliki pengaruh terhadap tingkat kepatuhan membayar pajak.

Terdapat 2 macam respon atau persepsi wajib pajak UMKM terhadap PP no 46 tahun 2013 yaitu respon positif dan respon negative. Dari 23 responden (92\%) dari 25 responden wajib pajak wajak UMKM mempunyai respon positif dalam kemudahan dalam menghitung pajak sedangkan 20 responden ( $80 \%$ ) dari 25 responden negative asas keadilan, mereka mengatakan bahwa peraturan PP 46 tahun 2013 tidak memenuhi asas keadilan karena merugikan pengusaha dengan margin keuntungan kecil. Selain itu bagi WP OP kehilangan fasilitas PTKP, dan tidak ada lagi fasilitas kompensasi kerugian

Para pengusaha UMKM umumnya mengatakan bahwa usaha yang digeluti berkembang, perkembangan ini karena infut yang digunakan dalam proses produksi mudah didapat dan begitu pula pesediaan barang dagangan yang didukung oleh adanya daya beli Masyarakat untuk produk produk UMKM dan barang dagangan. Namun dari memenuhi kewajibannya umum responden atau semua responden 23 (92 \%) responden merasa berat dalam memenuhi kewajibannya karena besarnya pajak yang dibayar. Begitupula juga pendapat yang sama dari informan yang diperoleh di dalam pelaksanaan Focos Group Discussion (FGD) pada waktu melakukan kegiatan pengabdian kepada Masyarakat. Berdasarkan uraian ini, maka respon Wajib pajakak UMKM terhada PP no 46 tahun 2013, ada respon yang positif dan ada yang negative. Respon yang positive adalah terpenuhi asas kemudahan menghitung pajak dan yang negative adalah asas keadilan tidak terpenuhi karena WP UMKM di Kecamatan Ampenan merasa berat dalam penuhan kewajiban perpajakannya setiap bulan menyebabkan ada sebagian wajib pajak tidak patuh dalam memenuhi kewajiban perpajakannya.

\section{SIMPULAN}

1. Umumnya WP UMKM di Kecamatan Ampenan sudah memahami keberadaan PP no 46 tahun 2013 tentang tarif $1 \%$ dari jumlah peredaran bruto perbulan dan bersifat final. Berdasarkan data dari 25 responden WP UMKM di Kecamatan Ampenan diktahui bahwa sebanyak 21 (84\%) pengusaha UMKM sudah memahami ketentuan peraturan ini. Tingginya tingkat pemahaman pengusaha UMKM dikecamatan Ampenan karena pemerintah dalam hal ini aparat pajak giat mengadakan sosialisasi secara langsung maupun tidak langsung.

2. Ada dua macam respon Wajib pajakak UMKM terhada PP no 46 tahun 2013, yaitu respon yang positif dan ada yang negative. Respon yang positive adalah terpenuhi asas kemudahan menghitung pajak dan yang negative adalah asas keadilan tidak terpenuhi karena WP UMKM di Kecamatan Ampenan merasa berat dalam penuhan kewajiban perpajakannya setiap bulan menyebabkan ada sebagian wajib pajak tidak patuh dalam memenuhi kewajiban perpajakannya. 


\section{DAFTAR PUSTAKA}

Anonim, Direktorat Jendral Pajak 2013. Menanamkan Pemahaman PP 46 Tahun 2013.http://www.pajak.go.id/content/flash-foto/menanamkan-pemahamanpp-46-tahun-2013-kepada-masyarakat-mempawah tanggal 9/10/2013 Pukul $\underline{15.03}$ diakses pada tanggal 9/10/2013 pukul 15.50 WIB.

Undang-Undang No. 20 Tahun 2008. http://www.danabergulir.com/peraturanperundangan/undang-undang/UU20Tahun2008UMKM.pdf diakses pada tanggal 9/10/2013 pukul 15.58 WIB.

Akhir, Dani Jumadil. 2013. Dua Sisi Kebijakan Pajak UMKM. Okezone. http://economy.okezone.com/read/2013/09/17/317/867391/dua-sisikebijakan-pajak-UMKM diakses pada tanggal 9/10/2013 pukul 15.47 WIB.

Baiquni, Ahmad. 2013. Pajak UMKM Dinilai Belum Layak Diterapkan. Merdeka. http://www.merdeka.com/uang/pajak-umkm-dinilai-belum-layakditerapkan.html diakses pada tanggal 9/10/2013 pukul 15.28 WIB.

Bramantyo, 2013. Kena Pajak Laba UMKM Makin Tergerus. Okezone. http://economy.okezone.com/read/2013/08/15/320/850029/kena-pajak-labaUMKM-makin-tergerus diakses pada tanggal 9/10/2013 pukul 15.45 WIB.

Budianto, Arif. 2013. Pengusaha Minta Pajak UMKM Tak Dipukul Rata. Sindo News. http://ekbis.sindonews.com/read/2013/09/26/33/787863/pengusaha-mintapajak-UMKM-tak-dipukul-rata diakses pada tanggal 9/10/2013 pukul 15.10 WIB.

Call Center Kota Mataram 112, Email : pelayanan@mataramkota.go.id. WWW.Mataram kota.go.id/opd-50-Kecamatan Ampenan

Djumena, Erlangga. 2013. Sanksi Pajak UMKM Dihapus. Bisnis Keuangan. http://bisniskeuangan.kompas.com/read/2013/09/06/0800138/Sanksi.Pajak.U MKM.Dihapus diakses pada tanggal 9/10/2013 pukul 15.25 WIB.

Herdiman, Fransiskus Saverius. 2013. Menyoal Pengenaan pajak Untuk UMKM. Jurnas. http://www.jurnas.com/news/99011/Menyoal Pengenaan Pajak untuk UMKM/1/Ekonomi/Ekonomi diakses pada tanggal 9/10/2013 pukul 17:23 WIB. 
Hermawan, Erwan. 2013. Pajak UMKM Belum Final. Tempo. http://www.tempo.co/read/news/2013/09/17/090514041/Pajak-UMKM-BelumFinal diakses pada tanggal 9/10/2013 pukul 15.30 WIB.

Novianti, Fiska. 2013. Ditjen Pajak Dorong Penerimaan Pajak dari UMKM. Suara Merdeka. $\quad$ http://www.suaramerdeka.com/v1/index.php/read/news/2013/ 09/25/173276/Ditjen-Pajak-Dorong-Penerimaan-Pajak-dari-UMKM- diakses pada tanggal 9/10/2013 pukul 15.03 WIB.

Sobarudin, Arif. 2013. Ciri-Ciri dan Contoh Usaha Kecil. Bisosial. http://www.bisosial.com/2013/08/ciri-ciri-dan-contoh-usaha-kecil.html diakses pada tanggal 10/12/2013 pukul 14.25 WIB.

Sobarudin, Arif. 2013. Kelebihan dan Kelemahan Usaha Kecil. Bisosial. http://www.bisosial.com/2013/08/kelebihan-dan-kelemahan-usaha-kecil.html diakses pada tanggal 10/12/2013 pukul 14.30 WIB.

Sulystyawati, Laeny. 2013. Ekonom: UMKM Berat Untuk Usaha Beromzet Di Bawah Rp 1 Miliar. Republika.http://www.republika.co.id/berita/ekonomi/ mikro/13/08/07/mr542u-ekonom-pajak-umkm-berat-untuk-usaha-beromzetdi-bawah-rp-1-miliar diakses pada tanggal 9/10/2013 pukul 15.14 WIB.

Sulystyawati, Laeny. 2013. Tiga Alasan Mengapa Hipmikindo Minta Penundaan Pajak UMKM. Republika. http://www.republika.co.id/berita/ekonomi/ mikro/13/08/06/mr3lks-tiga-alasan-mengapa-hipmikindo-minta-penundaanpajak-umkm diakses pada tanggal 9/10/2013 pukul 15.15 WIB.

Sutaryono, Paul. 2013. Menimbang Efektivitas Pajak. Okezone. http://economy.okezone.com/read/2013/08/22/317/853633/menimbangefektivitas-pajak-umkm diakses pada tanggal 9/10/2013 pukul 15.00 WIB.

Wiyanto, Dian Siko Sigit. 2013. Pajak UMKM 1\% Dari Omzet. Pengusaha Muslim. http://pengusahamuslim.com/pajak-umkm-1-dari-omzet-1866\#.UlUahNJkM80 diakses pada tanggal 9/10/2013 pukul 15.20 WIB. 